\title{
IMPACT OF COVID-19 ON TOURISM IN GEORGIA-AN OVERVIEW
}

\author{
Nana Kvirkvelia ${ }^{*}$, Mariam Tsitsagi ${ }^{1}$
}

\begin{abstract}
Coronavirus has posed a great challenge to the whole world, including Georgia. The restrictions have taken a heavy toll on the tourism industry worldwide. It has been clear since the spring of the current year that the mass recovery of international tourism will not be possible by 2020. Consequently, the necessity has led to changes, especially in the direction of domestic tourism. Countries apply different strategies. This review article is based on the results of a mini-survey and data from the National Statistics Office. It is analyzed what impact COVID-19 had on local tourism in Georgia, what is the public mood, which places were visited, where did the epidemic break out after the restrictions were lifted, what are the statistics of international tourists in Georgia, etc. Besides, tourism support measures developed around the world are discussed.
\end{abstract}

Keywords: COVID-19, tourism, Georgia

\section{Introduction}

It is generally accepted that the COVID-19 pandemic has changed the whole world. It has had a significant impact on the international tourism industry. This branch of economics has lost its relevance for some time. Flights around the world have been suspended, tourist traffic and the hotel industry have ceased to function. Mass tourism and over-tourism are no longer a problem. Even more, it is tourism that has become one of the main drivers of the epidemic. Studies show that in the early stages of the epidemic, there was a correlation between international tourism and the level of infection (Farzanegan et al., 2020).

It has been repeatedly suggested that coronavirus infection will persist for several years and we will have to live with it. Consequently, the tourism sector also faced many challenges. Consequently, tourism needs to be transformed and changed (Gössling et al., 2020). The epidemic crisis is forcing us to find the rare and best way to develop tourism for a better future. Changes need to be made that focus on the interests of local communities and the protection of their rights. According to some scientists, in theory, such approaches to the welfare of society will "socialize" tourism (Higgins-Desbiolles, 2020). This in turn forces tourism to be accountable to the world's social and environmental constraints. Demand is likely to increase for safe places where social distance protection will be possible. The whole world, as well as Georgia, is facing this challenge. Such types of tourism as eco, agro and rural tourism should be activated. The local population will be able to turn the income from tourism services into additional income, and the production of agricultural products will

\footnotetext{
${ }^{1}$ TSU, Vakhushti Bagrartioni Institute of Geography, Tamarashvili 6, 0177. Tbilisi, Georgia, nana.kvirkvelia@tsu.ge
} 
become their main source of income. It is a good fact that National Geographic, one of the most influential travel publications in the world, named Georgia, Svaneti region, among the 25 best destinations in the world in 2021, which tourists should visit in the post-pandemic period (National Geographic, 2020).

Some scholars are talking about the transition to the tourism industry using the "Buen Vivir" method. This is a South American concept that implies the local and slow development of tourism, which, in itself, will contribute to the protection of nature and benefit both the host local communities as well as the tourists. This concept serves the well-being of all (Everingham \& Chassagne, 2020).

According to the National Tourism Agency, in February 2020, the number of tourist visits to Georgia increased by $+4 \%$, while international traveler visits decreased by $0.7 \%$. The development of domestic tourism, of course, is not associated with large revenues, but it will allow the country to develop sustainable tourism and more or less maintain the stability of the population involved in the tourism segment, and in fact, its existence depends on tourism. Several projects are already underway in Georgia (hotels in Georgian mountain resorts during the "Discount Week"), which will help to popularize the region and encourage domestic tourism. These projects will also help attract visitors to tourist facilities. According to Galt \& Taggart in its research, domestic tourism will be encouraged by the fact that in 2020 , the travel of Georgians abroad is limited. It should be noted that the measures of the support package of the Government of Georgia are similar to those of other countries, although there is one exception - Georgia has not stimulated domestic tourism. We think it is the duty of each of us to promote the development of local tourism. After some restrictions were lifted (meaning the summer period of 2020), to show solidarity, many Georgian citizens promoted various tourist facilities, accommodation, or food facilities through social networks.

Tbilisi hotels would be in the worst condition, which was to be expected, as it was unthinkable to bring a Georgian tourist or vacationer to the capital in the context of domestic tourism. Therefore, most of the hotels in Tbilisi are closed today, some of their employees were employed in hotels in the region, and representatives of the hotel business took an active part in this, some even had to temporarily change the field. The purpose of this review paper is to describe and examine the effect of the COVID-19 pandemic on tourism in Georgia.

\section{International tourism faces to COVID-19}

Countries around the world have developed anti-crisis plans to deal with COVID19 (Rogerson \& Rogerson, 2020), (Rutynskyi \& Kushniruk, 2020), (Sah et al., 2020), (Mariolis et al., 2020), (Foo et al., 2020), (Gil-Alana \& Poza, 2020). There are three main types of approaches: 1. Protecting people (e.g. Italy, Japan, Korea, Norway, Poland), which includes informing visitors, assisting in repatriation, etc. Financial support for people employed in the tourism sector. 2. Business maintenance (e.g. EU, Brazil, and Australia) includes financial support for tourism companies, especially small and medium-sized companies, assistance in finding new markets, updating work processes, etc. 3. Coordination mechanisms (e.g. Canada, France, Ireland, 
United Kingdom) - special groups to assess the impact of Covid-19 and response mechanisms (e.g. communication with the private sector, development of short-term, medium and long-term strategies, etc.).

Tourism support events have also been developed in various countries around the world. These include deferral (cancellation of taxes, access to loans), credit guarantees, financing of interest on loans, deferral of loans, wage subsidies, cash benefits for the unemployed, gift vouchers (programs to encourage inbound tourism retention, and invaluable tours). Support measures are similar in Georgia and other countries, except for domestic tourism incentives and vouchers.

A study published by Galt \& Taggart - a survey of hotels - identified the most critical problem with bank lending services. $73 \%$ of the hotel business would like to defer credit contributions by the end of $2020,66 \%$ would want to subsidize interest rates on loans, $65 \%$ would want tax breaks, and $31 \%$ would want to defer utility bills. These requirements were even met. There are other requirements that could not be met. Examples are access to loans (credit guarantees from the state), deferral of utility bills, employment programs (temporary employment of staff), and others (Galt \& Taggart, 2020).

\section{Georgia's Perspective}

Chronologically, we present the sequence of restrictions that Georgia adopted before the pandemic. After the virus has appeared, it became even more severe. The epidemiological chronology in Georgia looks like this: January 29 - Air traffic with China was suspended, February 24 - All types of traffic with Iran were suspended, February 26 - The first confirmed case of Covid-19 was recorded, March 4 - All types of traffic with Italy were suspended, March 18 - Borders were closed, March 21 State of emergency declared, March 31 - Universal quarantine declared, April 14 State of emergency extended, April 27 - First part of restrictions lifted, May 7 Tourism support package announced, May 21 - State of emergency ended, June 8 hotels and restaurants opened, July 1 - Borders with some countries open.

As a result of restrictions and timely response, the situation in Georgia was stable. Removing restrictions after being locked up for so long, it is interesting to see how events unfolded. It was during this period, in August 2020, that we conducted a small survey remotely. August in Georgia is a period of massive vacations, travel, with the addition of removed restrictions, both in the world and in Georgia. The research is not large-scale but based on it and by analyzing the ongoing processes in the country, we were able to make some conclusions. For example, what is the travel mood of the Georgian population during the fight against the pandemic, which places are popular, what followed these trips, etc.

The study included citizens of Georgia aged 16 and more, among whom the majority of females $-77.4 \%$. As we can see from fig. 1 the majority of the respondents $(76.9 \%)$ are people aged 30 to 50 years. 70 years and older $-10.3 \%$. 16 to 30 years $12.3 \%$.

As we have already mentioned, during the pandemic there were certain restrictions, curfew and intercity restrictions, which were obeyed by the citizens of 
Georgia. Presumably, this meant that the processes caused by COVD-19 in the first half of 2020 were manageable and did not result in many casualties, which we cannot say about the post-summer period. As we know, the spread of the epidemic is related to socialization, after the lifting of restrictions, the population began to travel, and it was during this period that a large influx of tourists headed to Svaneti. We note here that $71 \%$ of our respondents wanted to travel to Samegrelo-Zemo Svaneti. The virus spread, which, unfortunately, led to the closure of Svaneti. The next wave of the virus spread to the Black Sea coast. $57 \%$ of our respondents planned to spend their vacation here. It is also an important fact that $43 \%$ of respondents have already visited Mtskheta-Mtianeti region. An epidemic broke out in this area as well. 22.6\% traveled to Achara and $29.2 \%$ planned to travel to Achara. The fact is, the virus has spread rapidly to areas where people have been active. The main purpose of the trip was rest and recreation (68.2\%). Despite the created situation, $39 \%$ of them are satisfied.

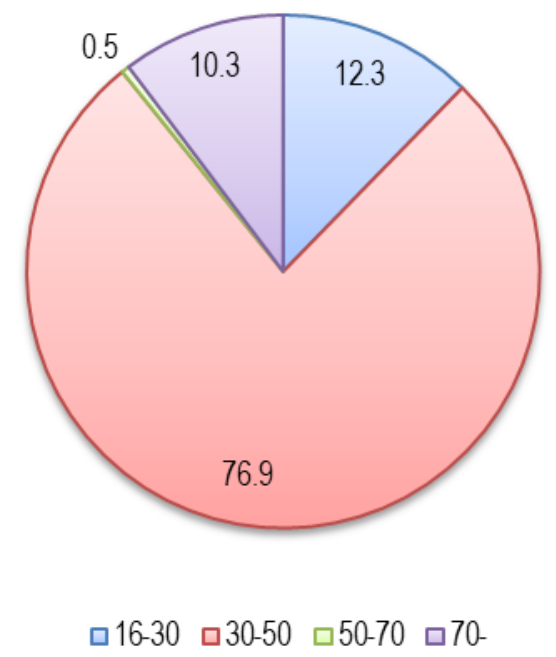

Fig. 1. Respondents' age

As we have already mentioned, domestic tourism is one of the ways to alleviate the crisis, but its share in Georgia is low - 26\% (Galt \& Taggart, 2020).

Compared to other countries, the scale of domestic tourism in Georgia is quite limited, as most locals do not visit hotels and rent private houses. Analyze the statistical data of the second quarter of 2020 by the National Department of Statistics of Georgia. The percentage of domestic visitors according to the cities visited is as follows: Tbilisi - 20\%, Batumi - 7, 7\%, Kutaisi - 7\%, Mtskheta - 2, 6\%, Rustavi - 2, $3 \%$, Gori $-1.7 \%$. The majority of their trip $(53.5 \%)$ was to visit relatives and friends (NSOG, 2020). Domestic tourists prefer to stay in a hotel when traveling, especially in Tbilisi. Only $0.6 \%$ of visitors spend the night in a hotel. $46.9 \%$ - with friends or relatives, and $49.9 \%$ - at home (Georgia, 2020). It is interesting what the statistics of visitor movement by regions of Georgia look like. From fig. 2, it can be seen that Tbilisi (20\%), Imereti (19.0\%), and Achara (11.5\%) take the top three places (NSOG, 2020).

The practice of "tourist bubbles" is settling in the world. Countries with similar epidemiological conditions open their borders to each other. There is a gradual return 
of tourists. In the first stage, significant emphasis is placed on neighboring countries, from where most visitors visit the country in their own cars. According to the data of the National Statistics Office of Georgia for the first quarter of 2020, the number of international visitors reached 883.8 thousand, which is a decrease of $15.2 \%$ compared to the same period last year. International visitors paid 765.3 thousand tourist types of visits, which is $13.2 \%$ less than the same period last year. The largest number of visitors - 197.2 thousand visitors - was recorded from Azerbaijan, which is $22.3 \%$ of the total visitors and represents a decrease of $7.3 \%$ compared to the corresponding figure for 2019. The largest number of visits (262.2 thousand) was made by citizens of Azerbaijan, which is $10.5 \%$ less than the same period last year. The majority of visitors $-48.7 \%$, belonged to the age group of 31-50 years. The number of women makes up $33.2 \%$ of the total visitors. In the first quarter of 2020, the most visits $31.9 \%$ - were made for leisure, entertainment, and recreation, mostly in Tbilisi and Kvemo Kartli, respectively, 559.3 thousand and 241.3 thousand. The average number of nights spent during visits in the first quarter of 2020 was 3.4 nights, which is $8.8 \%$ less than the figure recorded in the first quarter of 2019 (3.7 nights). 83.7\% of the visits were repeated visits. Expenditures on visits in the first quarter of 2020 amounted to 1.0 billion GEL, which is $12.9 \%$ less than the same period last year. The average cost of a visit increased by $3.7 \%$ compared to the first quarter of 2019 and amounted to 922.4 GEL (NSOG, 2020).

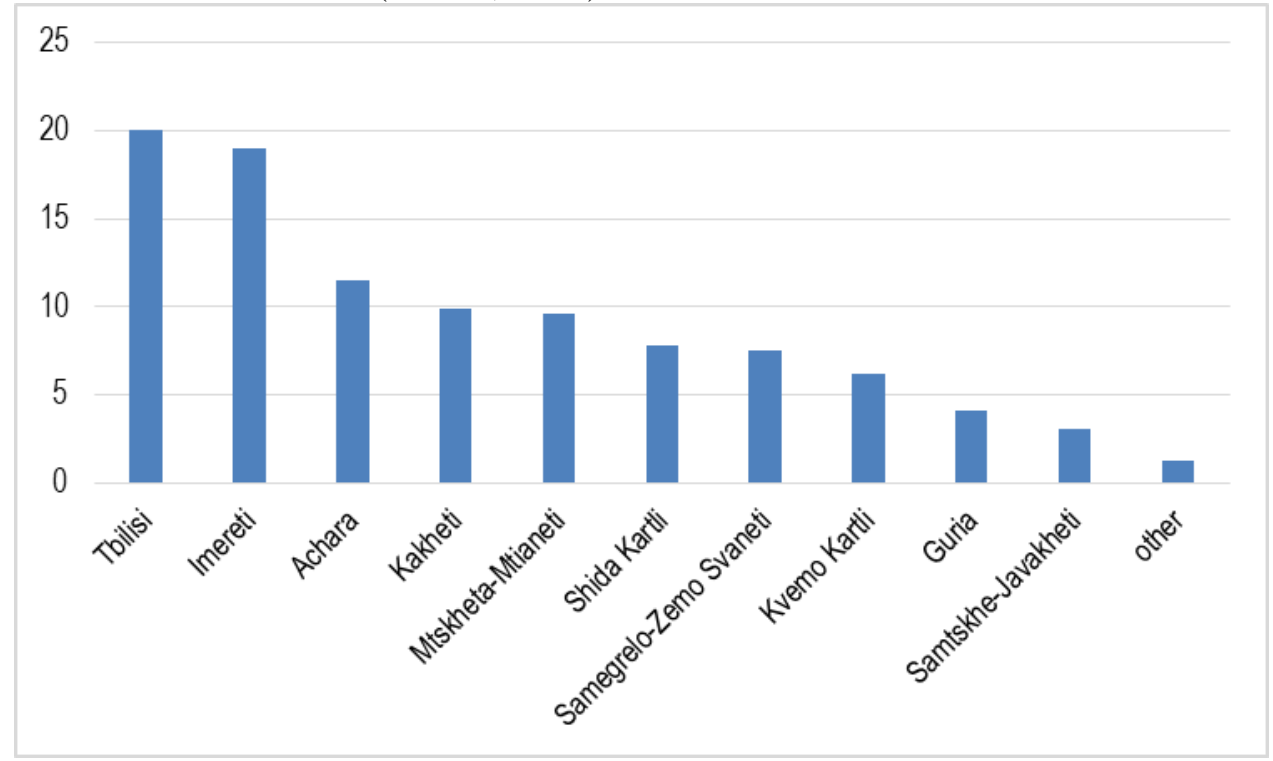

Figure 2. Visitors' movement by regions of Georgia

Azerbaijani and Armenian tourists mainly visit Georgia, and in the summer period, Georgia may become more attractive to them. In addition to the neighbors, it is necessary to explore new markets - Chinese tourists are increasingly interested in Georgia. The vast majority of Chinese tourists are low- or middle-income individuals, for whom mostly cheap tourist markets are available. China is the largest tourist market in the world. Most of them visit Asia and the Pacific, but there is a growing interest in developing tourism. According to Mafengwo.com, the most frequently 
used online travel information portal in China, in 2018, special attention was paid to Chinese tourists from Georgia, Turkey, Serbia, Cyprus, the Bahamas, and Croatia.

An updated strategy by hotels should be prepared due to the decrease in visitors. In the summer of 2020, some discounts were observed in family-type hotels. Due to the closure of the country's borders, many Georgians who were going abroad for vacation were forced to travel inside the country. As some hotel consultants point out, this factor has had a positive impact on the development of domestic tourism. The increased flow of Georgian tourists has increased competition between hotels for quality and cleanliness of services, which is often a pain/shortcoming of non-branded small facilities. This has shown the owners or managers of small and medium-sized hotels, restaurants, and managers that if before they had to count on foreign tours that came once and did not have to count on their repeat visit, now the situation has changed. As you know, the impression of the vacationer and satisfaction is of great importance. Georgians are always followed by their friends or acquaintances, so quality care has become even more necessary in a pandemic. Otherwise, the visitor will go elsewhere, since the hotel is a lot, the vacationer is a little, therefore, it is important to take care of the quality of food and service. Little progress has been made in this regard, which will hopefully be maintained in the future as the state spends quite a large budget and resources to popularize the country internationally. The incoming tourist must meet the appropriate quality so that there are no negative consequences in the future. The level of international visitor satisfaction is set by hotels, restaurants, and tours organized by travel companies, on which the state has no leverage yet.

\section{Conclusion}

The whole world, including Georgia, has suffered from the coronavirus. The restrictions have caused great damage to the tourism sector. It has become clear that mass tourism international recovery will not be possible by 2020. Consequently, the need has led to changes, especially in the direction of domestic tourism. When the borders are opened, security control will become relevant, in which it will be important to share the experience of other tourist countries. For example arrangement of quarantine areas in tourist destinations, test laboratories, allocation of doctors, control of social distance by drones on the beaches, Covid-19 testing at the airport, periodic temperature control in hotels and restaurants, the possibility of operating hotels with $25 \%$ occupancy; Restrictions for hotels, for example, accommodation of a maximum of 2 adults and 1 child in a room, and much more. The statistics mentioned in the article, the results of the mini-research, some recommendations will help the development of tourism in the conditions of coronavirus. 


\section{References}

Everingham P. Chassagne N. (2020). Post COVID-19 ecological and social reset: moving away from capitalist growth models towards tourism as Buen Vivir. Tourism Geographies, 22(3). https://doi.org/10.1080/14616688.2020.1762119

Farzanegan M. R. Gholipour H. F. Feizi M. Nunkoo R. Andargoli A. E. (2020). International Tourism and Outbreak of Coronavirus (COVID-19): A Cross-Country Analysis. In Journal of Travel Research. https://doi.org/10.1177/0047287520931593

Foo L. P. Chin M. Y. Tan K. L. Phuah K. T. (2020). The impact of COVID-19 on tourism industry in Malaysia. Current Issues in Tourism. https://doi.org/10.1080/13683500.2020.1777951

Galt \& Taggart. (2020). Tourism Challenges in the Second Half of 2020. Tbilisi: https://galtandtaggart.com/upload/reports/18723.pdf.

Gil-Alana L. A. Poza C. (2020). The impact of COVID-19 on the Spanish tourism sector. Tourism Economics. https://doi.org/10.1177/1354816620959914

Gössling S. Scott D. Hall C. M. (2020). Pandemics, tourism and global change: a rapid assessment of COVID-19. Journal of Sustainable Tourism. https://doi.org/10.1080/09669582.2020.1758708

Higgins-Desbiolles F. (2020). Socializing tourism for social and ecological justice after COVID-19. Tourism Geographies, 22(3), 1-15. https://www.tandfonline.com/doi/full/10.1080/14616688.2020.1757748

National Geographic (2020). Destinations on the rise for 2021. Retrieved from https://www.nationalgeographic.com/travel/features/best-of-the-world-2021/

NSOG (2020). www.geostat.ge. Retrieved from https://www.geostat.ge

Mariolis T. Rodousakis N. Soklis G. (2020). The COVID-19 multiplier effects of tourism on the Greek economy. Tourism Economics. https://doi.org/10.1177/1354816620946547

Rogerson C. M. Rogerson J. M. (2020). COVID-19 Tourism impacts in South Africa: Government and industry responses. Geojournal of Tourism and Geosites, 31(3). https://doi.org/10.30892/gtg.31321-544

Rutynskyi M. Kushniruk H. (2020). The impact of quarantine due to COVID-19 pandemic on the tourism industry in Lviv (Ukraine). Problems and Perspectives in Management, 18(2). https://doi.org/10.21511/ppm.18 (2).2020.17

Sah R. Sigdel S. Ozaki A. Kotera Y. Bhandari D. Regmi P. Rabaan A. A. Mehta R. Adhikari M. Roy N. Dhama K. Tanimoto T. Rodríguez-Morales A. J. Dhakal R. (2020). Impact of COVID-19 on tourism in Nepal. In Journal of travel medicine (Vol. 27, Issue 6). https://doi.org/10.1093/jtm/taaa105 